\title{
PEMBERDAYAAN DESA PRIMA SENDANGAGUNG: MENGELOLA DAN MEMASARKAN PRODUK BERBASIS LELE
}

\author{
Mohamad Irhas Effendi 1, Bambang Sugiarto ${ }^{2}$, Jubaedah Nawir 3 \\ 1 Universitas Pembangunan Nasional "Veteran" Yogyakarta \\ 2 Universitas Pembangunan Nasional "Veteran" Yogyakarta \\ 3 Universitas Pembangunan Nasional "Veteran" Jakarta \\ ${ }^{1}$ E-mail address $\underline{m}$ irhaseffendi@upnyk.ac.id; 2 E-mail address \\ bambang tekim@upnyk.ac.id;3 E-mail address jubaedah@upnvj.ac.id
}

\begin{abstract}
Sendangagung Village is one of the villages in Sleman which has several catfish farms to help the community's economy. Besides being cheap and easy to get, catfish has a variety of nutrients that are good for the body. However, in catfish farming, it is not an easy thing. Because there are so many farmers who actually experience losses in catfish farming because the selling price is too low. In addition, there is a Desa Prima consisting of Sendangagung women, an alternative or breakthrough in efforts to empower women in the economy through increasing women's empowerment and increasing income women, especially poor families. This service intends to combine the two groups above to solve common problems, namely the Catfish Farmer Group and Desa Prima Sendangagung through four stages, namely program socialization, mentoring, education and training, and post-training partner monitoring. Desa Prima Sendangagung will obtain relatively cheap raw materials which will be processed into various products and sold online. Meanwhile, catfish farmers will benefit from having no trouble marketing their crops.
\end{abstract}

Keywords: Prima Village, Product Quality Improvement and Digital Marketing.

\begin{abstract}
Abstrak
Desa Sendangagung merupakan salah satu desa di Sleman yang memiliki beberapa tempat ternak lele untuk membantu perekonomian masyarakat. Selain harganya yang murah dan mudah didapat, ikan lele mempunyai berbagai nutrisi baik bagi tubuh. Namun dalam budidaya ikan lele, bukan suatu hal yang mudah. Karena banyak sekali peternak yang justru mengalami kerugian dalam ternak ikan lele karena harga jual yang terlalu rendah. Selain itu terdapat kelompok Desa Prima yang terdiri dari para perempuan Sendangagun suatu alternatif atau trobosan dalam upaya pemberdayaan perempuan dalam bidang ekonomi melalui peningkatan pemberdayaan perempuan dan peningkatan pendapatan kelompok perempuan khususnya keluarga miskin. Pengabdian ini berniat untuk memadukan kedua kelompok di atas untuk memecahkan permasalahan bersama, yakni Kelompok Peternak lele dan Kelompok Desa Prima
\end{abstract}


Sendangagung melalui empat tahap yaitu sosialisasi program, pendamoingan, Pendidikan dan pelatihan, dan pemantauan mitra pascra pelatihan. Kelompok Desa Prima akan memperoleh bahan baku yang relative murah yang akan diolah menjadi berbagai produk dan dijual berbasis online. Sementara itu, peternak lele akan mendapatkan keuntungan yaitu tidak kesulitan memasarkan hasil panennya

Kata Kunci: Desa Prima, peningkatan kualitas produk dan pemasaran digital.

\section{PENDAHULUAN}

Permasalahan

pemberdayaan masyarakat dan desa adalah belum optimalnya peran dan fungsi kelembagaan masyarakat desa, peran perempuan dalam pembangunan dan tata kelola pemerintahan desa. Masyarakat di Desa Sendangagung mengalami kendala dalam mengelola berbagai sumber daya yang masih belum terkelola secara maksimal. Contohnya di Desa Sendangagung terdapat banyak masyarakatnya yang memiliki kolam lele dan nila tetapi biasanya mereka hanya menjual kepada konsumen berupa ikan mentah atau nugget saja sehingga dirasa potensi sumber daya ini belum secara maksmial dimanfaatka, diharapkan ikan yang ada dapat dikelola dengan baik dang menghasilkan berbagai macam olahan yang mampu berdaya jual tinggi. Isu strategis pada urusan perikanan adalah belum optimalnya tata guna dan tata kelola air serta fungsi kelembagaan petani, pembudidayaan perikanan, dan masih kurangnya kesadaran masyarakat akan melestarikan ekosistem perairan.
Sebagian besar kegiatan perikanan merupakan budidaya lele untuk kegiatan pembesaran sehingga dibutuhkanya bibit lele dan nila yang tinggi serta pengelolaan hasil perikanan yang belum optimal karena biasanya hanya dijual kiloan saja atau untuk dipancing.

Virus Corona atau dikenal juga dengan COVID-19 telah menyerang banyak negara, termasuk Indonesia. Pandemi ini menyebabkan kerugian besar di berbagai sektor. Salah satu sektor yang sangat terlihat dampaknya adalah sektor perekonomian. Banyak korporasi ataupun UMKM yang harus gulung tikar karena adanya pemerosotan kinerja dalam bisnisnya. Akibatnya, tingkat pengangguran di Indonesia meningkat kira-kira 4 hingga 5,5 juta orang (Gusman, 2020). Dari adanya dampak buruk pada sektor perekonomian, maka sektor peternakan secara langsung juga menghadapi kerugian yang besar. Menurut ketua Persepsi (Perhimpunan Ilmuan Sosial Ekonomi Peternakan Indonesia), Budi Guntoro (2020), dalam webinar nasional 
Persepsi, hal ini mulanya disebabkan oleh nilai tukar rupiah yang mengalami devaluasi dan mempengaruhi tingginya harga bahan baku impor untuk industri peternakan. Selain itu, turunnya pendapatan keluarga menyebabkan rendahnya daya beli terhadap bahan pangan asal ternak. Salah satu contoh sektor peternakan yang terdampak adalah peternakan ikan lele.

Permasalahan ini ditimbulkan oleh biaya pakan yang meningkat dan menurunnya serapan pasar seiring dengan adanya peraturan pemerintah perihal Pembatasan Sosial Berskala Besar (PSBB) dan pembatasan operasional usaha. Perihal ini membuat harga ikan lele turun dari harga jual biasanya (Suyatra, 2020). Walau harga ikan lele telah turun, minat beli masyarakat tetap rendah, sehingga peternak ikan lele ini tidak dapat menjualnya.Dari segi sisi Peran teknolgi sebagai salah satu alat pembangunan desa saat ini. Desa Sendangaung belum memaksimalkan pembangunan desa, baik dalam pembangunan infrastruktur sampai pembangunan desa berbasis teknologi. Pemasaran yang dilakukan di Desa Sendangagung masih belum sepenuhnya berbasis online sehingga masih kesulitan untuk mengembangkan dan memperluas pasar.

Berdasarkan uraian di atas dan hasil diskusi melalu video call secara mendalam dengan Pengurus Kelompok ikan Sendangagung dan Pengurus Desa prima serta pengusul dapat diidentifikasi permasalahan-permasalahan yang dihadapi oleh kedua mitra. Permasalahan ditemukan dari beberapa hal yang dirasakan menghambat pertumbuhan usaha atau bahkan mengancam kelangsungan usaha. Permasalahan yang diidentifikasi kemudian disusun berdasarkan skala prioritas penanganannya. Pengabian masyarakat ini menghasilkan beberapa program untuk mengatasi permasalahan yang telah diuraikan diatas, yaitu : program dan pelatihan pembuatan berbagai olahan lele, program pelatihan packaging dan labeling, program, pelatihan pemasaran, dan program pembuatan pakan lele. Program dilaksanakan bertahap selama tiga bulan Bersama dengan masyarakat desa Sendangagung terutama anggota Desa prima agar mampu mendorong perekonomian mereka.

\section{METODE DAN PELAKSANAAN}

\section{Metode}

Metode pelaksanaan yang digunakan untuk mengatasi permasalahan adalah pendampingan teknik budidaya dan pemasaran. Metode pelaksanaan kegiatan meliputi : materi 
pelatihan menggunakan media transfer teknologi berupa modul tertulis, tayangan, dan video serta praktek secara langsung di lapangan. Rencana kegiatan $\mathrm{PbM}$ juga telah disepakati yang merupakan turunan dari solusi yang ditawarkan. Setiap solusi harus diakses dengan aktivitas sehingga setiap permasalahan akan mendapatkan treatment penanganan. Kedua mitra memiliki permasalahan yang dapat dipecahkan secara bersama-sama. Peternak lele dapat menjadi suplier bagi UKM memproduksi olahan lele dengan harga wajar, lebih tinggi dari pada harga tengkulak. Sementara itu UKM mendapatkan pasokan bahan baku secara cukup dari peternak dengan harga wajar pula. Jalinan kerja sama ini dapat dilakukan dengan baik jika kedua mitra ditingkatkan produktivitasnya baik secara kuantitatif maupun kualitatif. Peningkatan alat dan sarana prasarana pendukung untuk kedua mitra menjadi keharusan agar produktivitas meningkat. Pengadaan sarana pembuatan pakan lele berkualitas bagi peternak harus dilakukan. Mitra kedua juga harus difasilitasi dengan alat kemasan dan olahan lele sehingga kualitasnya meningkat didukung akses pemasaran secara online. Metode pelaksanaan kegiatan menjelaskan tahapan atau langkah-langkah dalam melaksanakan solusi yang ditawarkan untuk mengatasi permasalahan. Kegiatan ini dilakukan selama 3 bulan dan didukung oleh Kepala Desa Sendangagung dan seluruh aparatnya, juga tokoh masyarakat, serta masyarakat (bapak, ibu dan pemuda/pemudi).

\section{Pelaksanaan Kegiatan}

Program pelatihan pertama dilaukan pada Sabtu, 19 Juni 2021 yang dihadiri oleh Dr. Mohammad Irhas Effendi, M.S.i sebagai ketua pengabdian, amggota, mahasiswa, serta masyarakat Sendangagung. Jumlah peserta dibatasi sebanyak 12 orang dan menerapkan protocol kesehatan. Peserta pada pelatihan ini merupakan anggota Desa Perempuan Indonesia Maju Mandiriyang menjadi target utama untuk menanggulangi kemiskinan melalui upaya ekonomi dengan memanfaatkan seluruh potensi/sumber daya baik alam maupun manusia. Pertama para peserta melakukan program dan pelatihan pembuatan berbagai olahan lele seperti nuget, abon, sup kepala lele, dan bakso ikan. Selanjutnya adalah program pelatihan packing dan labeling produk-produk yang sebelumnya telah dibuat agar produk olahan lele memiliki nilai lebih dan berdaya jual. Selanjutnya program dan pelatihan pemasaran, sistem pemasaran yang tepat penting bagi 
keberlangsungan usaha budidaya ikan pemasaran dapat dilakukan untuk lele, agar dapat menghasilkan mendapatkan keuntungan berlipat. pendapatan yang maksimal bagi Bisnis terus berkembang dan ikan lele peternak. Berbagai macam bentuk yang dipanen semakin banyak.
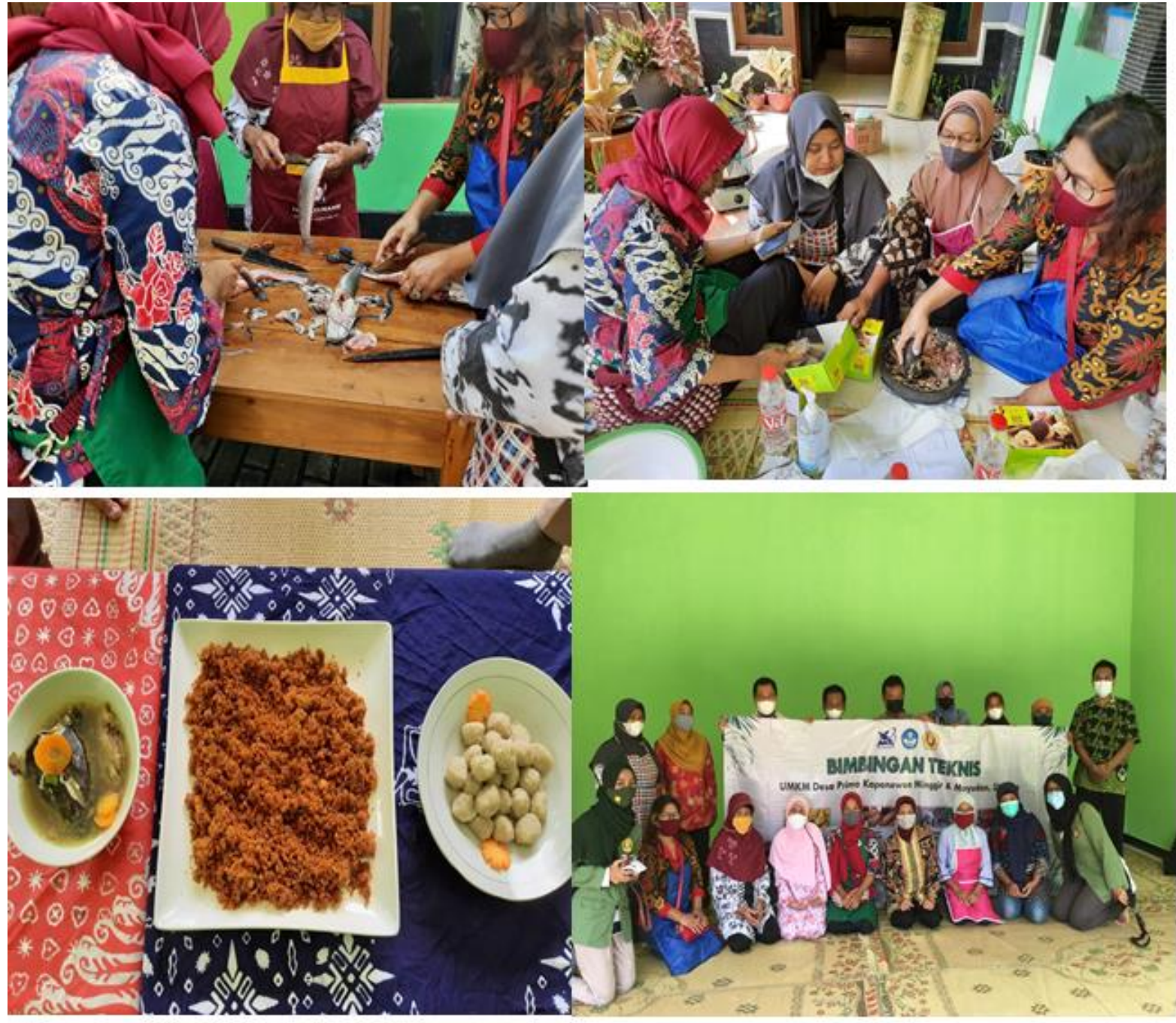

Gambar 1. Bimtek Pengolaan Produk Berbasis Lele

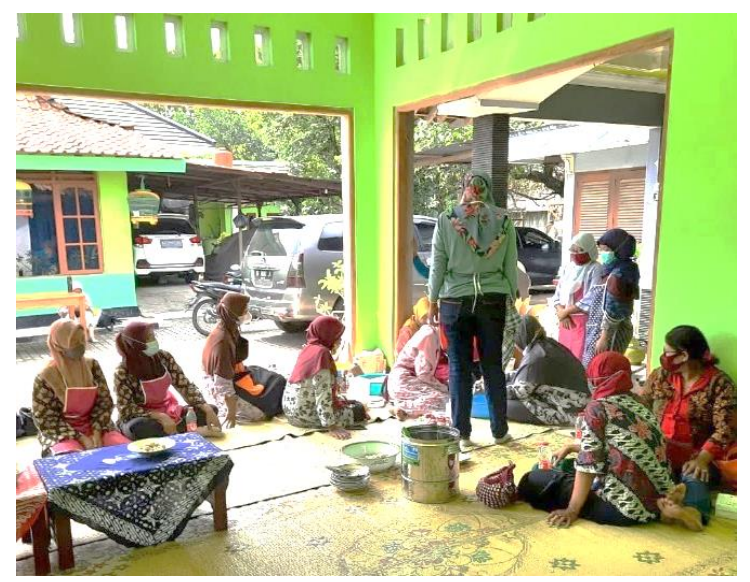

Pemasaran

Gambar 2. Program dan Pelatihan 


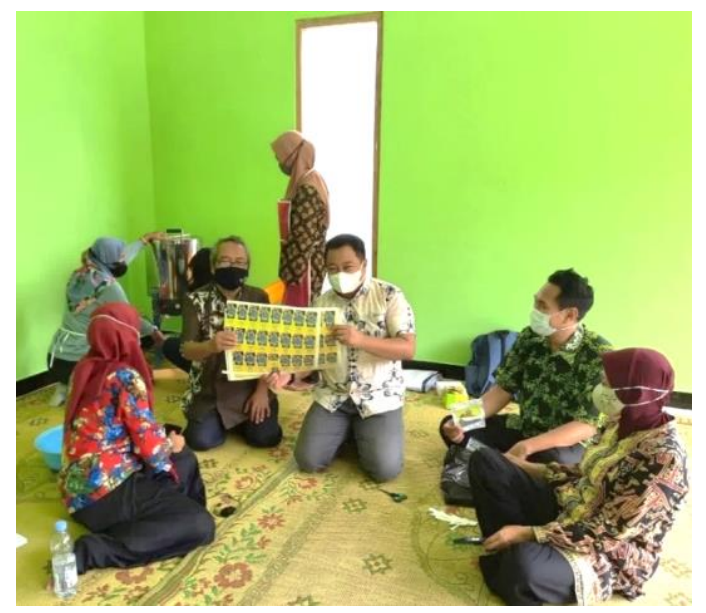

Gambar 3. Program Packing dan labeliing

Program pelatihan kedua dilakukan pada hari Minggu, 20 Juni 2021, yang dihadiri oleh 8 peserta yang merupakan pembudidaya lele dengan permasalahan harga pakan selama ini cenderung tinggi dan terus-menerus naik dan kualitas pakan yang kurang. Pengabdian ini memberikan fasilitas berupa alat alat pembuat pellet ini digunakan untuk mencetak pelet dengan lebih, lebih praktis dan lebih cepat sehingga dapat menuntaskan permasalahan para peternak yang mengeluhkan harga pellet lele yang mahal.

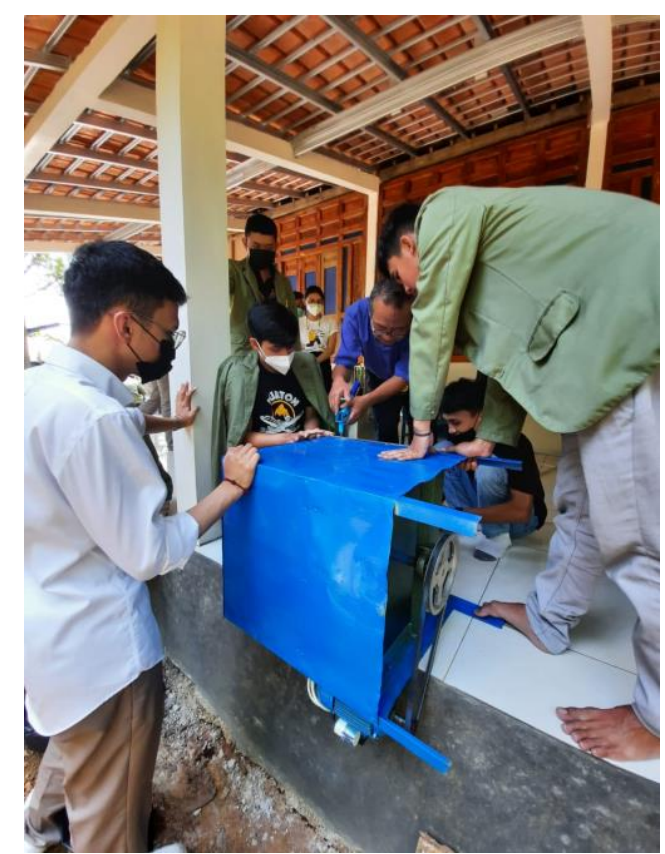

Gambar 4. Program Pembuatan Pakan Ikan

\section{HASIL DAN PEMBAHASAN}

\section{Hasil}

Tabel 1. Indikator Keberhasilan

\begin{tabular}{|c|c|}
\hline Indikator Keberhasilan & Uraian \\
\hline 1. Ilmu pengolahaan Lele & $\begin{array}{l}\text { Peserta berhasil membuat berbagai olahan } \\
\text { ikan lele (nuget, abon, sup kepala lele, dan bakso } \\
\text { ikan) yang dilakukan secara bersama-sama } \\
\text { sehingga menambah value ikan lele. }\end{array}$ \\
\hline $\begin{array}{l}\text { 2. Memahami pemasaran } \\
\text { digital }\end{array}$ & $\begin{array}{l}\text { Desa Prima Sendang agung memasarkan } \\
\text { produk berbasis online melalui media sosial } \\
\text { seperti FBdan Instagram, serta pembuatan web } \\
\text { maupun pemasaran melalui e-marketplace } \\
\text { seperti shopee, tokopedia, dll. }\end{array}$ \\
\hline
\end{tabular}




\begin{tabular}{|l|l|}
\hline $\begin{array}{l}\text { 3. Packaging dan Labeling } \\
\text { produk }\end{array}$ & $\begin{array}{l}\text { Membuat desain label dan packing dari } \\
\text { pembuatan kemasan mulai dari pembuatan } \\
\text { desain, pembentukan, dan finishing akhir }\end{array}$ \\
\hline 4. Pakan lele berkualitas & $\begin{array}{c}\text { Peserta memiliki alat dan mampu } \\
\text { mengoperasikan untuk mengolah pakan lele. }\end{array}$ \\
\hline
\end{tabular}

\section{Pembahasan}

1. Program dan Pelatihan Pembuatan Berbagai Olahan Lele

Program Partisipasif Budidaya, pengolahan, dan pemasaran Ikan Lele ternyata mendapat sambutan hangat warga masyarakat. Ikan lele merupakan salah satu komoditas yang tidak biasa dalam perdagangan. Ikan pada umumnya akan lebih ekonomis harganya ketika ukurannya semakin besar. Namun, ikan lele akan turun harganya saat ukurannya terlalu besar. Kendala modal pakan yang besar untuk budidaya menyebabkan pembudidaya harus berpikir melakukan dan menciptakan inovasi agar perkonomian dapat terus berlanjut. Usaha yang dilakukan untuk menghindari persaingan penjualan ikan lele adalah dengan diversifikasi olahan. Penjual umumnya menjual ikan lele dalam bentuk mentahan dan belum diolah untuk olahan pecel lele. Rendemen ikan lele yang umumnya dimanfaatkan adalah dagingnya. Pengolahan ikan lele menjadi produk lain bertujuan untuk meningkatkan minat masyarakat terhadap ikan lele tersebut karena tidak semua lapisan masyarakat ingin mengkonsumsi ikan lele dalam keadaan utuh (misalnya pecel lele atau lele goreng).

Dengan pertimbangan tersebut di atas dan melihat karakteristik ikan lele maka sangat besar peluang untuk mengembangkan ikan lele menjadi berbagai produk olahan di Sendangagung. Disamping itu diversifikasi olahan lele ini dapat meningkatkan konsumsi protein hewani khususnya ikan bagi masyarakat Indonesia. Banyak yang tidak menyangka kalau ikan yang dikenal dengan patil tajamnya ini bisa dibuat berbagai jenis olahan yang sangat gurih, bergiji tinggi serta disukai oleh seluruh lapisan masyarakat. Pelatihan ini membuat bentuk diversifikasi olahan dilakukan adalah nuget, abon, sup kepala lele, dan bakso ikan yang diikuti oleh anggota Desa Prima Sendangagung. 2. Program dan Pelatihan Pemasaran Budidaya ikan lele atau ternak ikan lele sedang banyak diminati dan menjadi salah satu peluang bisnis yang dianggap memberikan keuntungan besar bagi peternak. Ikan lele merupakan jenikan ikan yang mudah dalam perawatan dan 
pemasarannya karena banyak dicari oleh Indonesia. ada budidaya ikan lele skala kecil, memasarkan ikan lele bukanlah perkara yang sulit. Meski demikian, peternak harus mengetahui strategi pemasaran yang tepat agar budidaya ikan lele mendapatkan keuntungan maksimal. Tanpa adanya pemasaran yang baik, usaha akan semakin menurun bahkan gulung tikar. Sistem pemasaran yang tepat penting bagi keberlangsungan usaha budidaya ikan lele, agar dapat menghasilkan pendapatan yang maksimal bagi peternak. Alat dan strategi untuk berinteraksi dengan pelanggan telah berubah dengan munculnya media yang dibuat oleh konsumen. Kontrol manajer atas konten, waktu, dan frekuensi informasi semakin berkurang di era media sosial (Mangold \& Faulds, 2009). Beberapa ahli berpendapat bahwa, terlepas dari kendala sumber daya, UKM cenderung lebih berwirausaha, fleksibel, dan inovatif daripada rekan organisasi besar mereka. Berbagai macam bentuk pemasaran dapat dilakukan untuk mendapatkan keuntungan berlipat. Bisnis terus berkembang dan ikan lele yang dipanen semakin banyak. Namun, UKM belum sepenuhnya memanfaatkan saluran pemasaran digital untuk melibatkan pelanggan, mendukung pertumbuhan penjualan, dan keberlanjutan bisnis
(Taiminen \&Karjaluoto, 2015).

Digitalisasi di perikanan budidaya akan membuat nilai jual yang lebih tinggi, mendapatkan kepastian pasar, sarana dan prasarana usaha yang lebih efisien, kemudahan akses teknologi produksi yang pada akhirnya membuat usaha budidaya makin efisien sehingga pendapatannya pun bisa meningkat. Media sosial telah menyebabkan perubahan signifikan dalam strategi dan alat yang digunakan perusahaan untuk berkomunikasi dengan pelanggan. Menurut Mangold dan Faulds (2009) berpendapat bahwa "media sosial menggabungkan karakteristik alat IMC tradisional (perusahaan yang berbicara dengan pelanggan) dengan bentuk word-ofmouth yang sangat diperbesar (pelanggan berbicara satu sama lain) di mana manajer pemasaran tidak dapat mengontrol konten dan frekuensi informasi semacam itu. Investasi pun dapat dilakukan secara online, prosesnya makin efektif. Ini merupakan bukti positif dampak industri 4.o. Lewat program itu masyarakat pembudidaya bisa memanfaatkan aplikasi digital untuk meningkatkan efisiensi usahanya sehingga pendapatan mereka meningkat. Pendampingan anggota Desa Prima Sendang agung memasarkan produk berbasis online melalui media sosial seperti FBdan Instagram, serta pembuatan web maupun pemasaran melalui emarketplace seperti shopee, tokopedia, 
dll.

\section{Program Pelatihan Packaging dan Labeling}

Persaingan usaha, khususnya untuk kalangan UMKM, sekarang ini semakin berkembang dan semakin ketat persaingannya, setiap hari aneka produk baru bermunculan. Pembuatan desain packaging juga memerlukan beberapa pertimbangan agar menjadi sebuah kemasan menjadi efektif yang mampu "menjual". Hal ini menyangkut penentuan karakter desain grafis pendukungnya, warna, tipografi, ilustrasi, sifat produknya, dll. Segmen Pasar apakah itu lokal/daerah/regional, pedesaan, perkotaan, internasional/mancanegara. Hal ini akan berpengaruh pada penentuan desain grafis dan material /bahan untuk kemasannya, misal: dari kertas, kayu, plastik, bahan natural, kain, fiber, kulit, dll. Harga Jual Produk, murah, sedang, mahal. Hal ini berkaitan dengam sgmen pasar: kelas bawah-menengah atasekslusif. Sifat Produk: konsumtif, gift /souvenir, produk massal, produk pakai, dan lain-lain.

\section{Langkah-langkah Kegiatan PPM}

a. Tim pelaksana manfaat dan pentingnya fungsi kemasan pada peserta pelatihan. b. Tim pelaksana mempertunjukkan alat dan bahan yang digunakan dalam proses pembuatan kemasan.

c. Tim pelaksana mempertunjukkan contoh-contoh kemasan dari berbagai bahan

d. Tim pelaksana mendemonstrasikan proses pembuatan kemasan mulai dari pembuatan desain, pembentukan, dan finishing akhir.

4. Program Pembuatan Pakan Lele Peternak lele memiliki permasalahan harga pakan selama ini cenderung tinggi dan terus-menerus naik, sehingga pembudidaya ikan harus mengencangkan ikat pinggang karena harga panen mereka yang tidak kunjung naik. Tingginya harga pakan disebabkan beberapa bahan baku yang masih impor sehingga harganya mahal. Permasalahan yang sering ditimbulkan oleh pedagang pengumpul hasil panen pembudidaya ikan adalah mereka sering memainkan harga. Disaat ikan lele sedang banyak di pasaran, pedagang akan menghitung ikan lele pedaging yang ukurannya agak besar sebagai ikan lele BS. Sedangkan disaat ikan lele sedang jarang di pasaran 
(yang seharusnya harga ikan lele naik), pedagang akan bertahan dengan harga yang lama yang mengakibatkan pembudidaya ikan harus menjual hasil panennya agar tidak memelihara lebih lama lagi. Sehingga dibuatlah alat pembuat pakan lele secara mandiri. Alat pembuat pelet pakan ikan merupakan alat yang harus ada untuk mendukung rangkaian proses pembuatan pelet, keberadaan mesin yang satu ini membuat pekerjaan membuat pelet menjadi lebih cepat, mudah dan praktis, yang tidak kalah penting produk pelet yang dihasilkan lebih maksimal. Sesuai dengan namanya, mesin ini digunakan untuk memadatkan atau mencetak adonan pelet baik pelet ikan maupun pelet ternak sehingga siap diberikan kepada hewan peliharaan. Mesin pelet asli, yg menunjukan ukuran mulut (hooper) umpan masuk $=12$ " dan keluar = 8" dengan Saringan (pelet kayu 12 $\mathrm{mm}$, pelet ikan $8 \mathrm{~mm}$, pelet ayam $6 \mathrm{~mm}$ ), memiliki Spesifikasi genset 6,5 HP tenaga gas melon. Dimensi alat : Tinggi $108 \mathrm{~cm}$, Panjang $90 \mathrm{~cm}$, dan Lebar 45cm

\section{PENUTUP}

\section{Simpulan}

Simpulan menyajikan ringkasan dari uraian hasil dan pembahasan, mengacu pada permasalahan mitra, solusi, dan hasil yang dicapai.
Pengabdian masyarakat yang dilakukan di Desa sendangagung minggir sleman. Pengabdian ini dilakukan setelah melihat permasalahan yang ditemukan berupa perlunya suatu alternatif atau trobosan dalam upaya pemberdayaan perempuan dalam bidang ekonomi melalui peningkatan pemberdayaan perempuan dan tingginya harga pakan disebabkan beberapa bahan baku yang masih impor sehingga harganya mahal. Pemberdayaan ini dilakukan melalui empat program utama program dan pelatihan pembuatan berbagai olahan lele, program dan pelatihan pemasaran, program pelatihan packaging dan labeling, dan pembuatan pakan lele.

\section{Saran}

Program pengabdian masyarakat telah terlaksana dengan baik. Namun, terdapat hal yang harus diperhatikan. Pertama, diharapkan terdapat keberlanjutan program yang saat ini telah terbentuk sehingga diperlukan kerjasama monitoring progran yang sudah dilaksanakan. Kedua, menjalankan pemasaran produk-produk pada masyarakat umum. Ketiga, menjadikan Desa Prima Sumberagung yang bermitra dengan UPN "Veteran" Yogyakarta sehingga dapat selalu terpantau keberlanjutan program. Keempat, masyarakat dapat mengembangkan dasar-dasar dari program pengabdian yang sudah dilakukan. 


\section{UCAPAN TERIMA KASIH}

Terima kasih kepada Lembaga Penelitian dan Pengabdian kepada Masyarakat Universitas Pembangunan Nasional Veteran Yogyakarta, Indonesia yang telah memberikan dukungan dana untuk pengabdian ini. Ucapan terima kasih disampaikan kepada pihak-pihak yang telah berkontrubisi positif baik berupa finansial maupun moral pada pengabdian masyarakat 2021 sehingga program ini dapat terealisasikan dengan baik dari awal hingga akhir.

\section{DAFTAR PUSTAKA}

Mangold, W. \& Faulds, David. (2009). "Social media: The new hybrid element of the promotion mix". Business Horizons. 52. 357-365. 10.1016/j.bushor.2009.03.002.

Taiminen, Heini \& Karjaluoto, Heikki. (2015). "The usage of digital marketing channels in SMEs". Journal of Small Business and Enterprise Development. 22. 633651. 10.1108/JSBED-05-20130073 . 